Robert Wawer SJ

Papieski Wydziat Teologiczny w Warszawie

0000-0002-3001-5268

Collegium Bobolanum

DOI: 10.15290/std.2018.04.09

\title{
SZTUCZNA INTELIGENCJA - PRODUKT CZY PODMIOT?
}

\section{ARTIFICIAL INTELLIGENCE - PRODUCT OR PERSON?}

Science and technology have created machines that in many aspects resemble people in action, and even exceed them in the ability to recognize, in the speed of thinking and counting, in the memory capacity. Thus, the development of humanity is at a time when the difference between the abilities of a human person and the artificial creation begins to blur. This article tries to trace how human nature was understood over the millennia and how it must now be re-egzamined in the confrontation with the rapidly growing artificial intelligence over the last decades. How predictable is the further development of artificial intelligence, and how much more will it replace the human person, or even improve human nature? There are here emerging questions: anthropological - concerning the evolution of human nature, philosophical how much creation can exceed the creator, and ethical - about the human and machine dignity, and responsibility for deeds. Is human nature immutable or subjected to technological evolution? To what extent can we allow machines to manage successive areas of our life and will it not turn against a human? This article follows stages of anthropology in different cultures and at different stages of civilization, and raises questions related to the emergence of a new reality, radically changing human life and touching the very essence of human creation.

Key words: anthropology, artificial intelligence, person, human nature, identity, dignity, personalism, transhumanism. 


\section{Wstęp}

Współczesny rozwój elektroniki i informatyki sprawil, że konstruowane urządzenia swoim zachowaniem coraz bardziej naśladują umiejętności ludzkie, cechy natury ludzkiej, a nawet je przewyższają w wielu dziedzinach. Powszechnie używane telefony potrafią rozpoznawać ludzką mowę i realizować rozkazy tak przekazywane. Maszyny obliczeniowe potrafią coraz dokładniej przewidywać zjawiska pogodowe. Systemy kamer w miejscach publicznych rozpoznają tożsamość osób, a nawet ich stan emocjonalny. Komputery wygrywają z mistrzami świata np. w szachy i potrafią bezpiecznie prowadzić pojazdy samochodowe w ruchu ulicznym. Takie cechy tworzonych urządzeń nazywane są sztuczną inteligencją (AI, z ang. artificial intelligence). Obserwując dalszy rozwój takich układów i ich coraz powszechniejsze zastosowanie w sposób naturalny pojawia się pytanie dokąd dojdziemy w zakresie AI? Zanikające różnice w umiejętnościach między ludźmi i maszynami budzą pytania o podmiotowość tych urządzeń i o istotę człowieczeństwa. Nie są to pytania nowe, proces upodabniania się maszyny do człowieka zauważył i bardzo trafnie przewidział już polski pisarz science fiction, filozof i futurolog Stanisław Lem (1921-2006). W swoich dziełach dotykał tej problematyki i stawiał pytania naukowo-filozoficzne w formie beletrystycznej co to jest natura ludzka i czy jest możliwe stworzenie maszyny na wzór i podobieństwo człowieka .

\section{Kim jest człowiek?}

Pojawia się coraz bardziej natarczywie pytanie: czy sztuczna inteligencja to jeszcze produkt technologii czy już podmiot, który powinien być traktowany z podobnym szacunkiem, z jakim traktuje się człowieka? Czy jest to sztuczny twór, czy też forma emanacji człowieczeństwa, które powinno być traktowane podmiotowo? Dotychczas mianem podmiotu był określany człowiek. Kim jest człowiek i co decyduje o byciu człowiekiem? To pytania od zawsze obecne w życiu człowieka, ale w zmieniającej się perspektywie nabierają nowego znaczenia. Człowiek, jako istota świadoma swojego istnienia i świata, od zawsze stawiał pytania w trzech obszarach: (1) o siebie: kim tak na prawdę jest?;

Lem ukazywał zacieranie różnicy pomiędzy człowiekiem a sztucznie skonstruowaną inteligentną maszyną już od 1957 roku (w cyklu opowiadań Dzienniki gwiazdowe z 1957 roku aż do ostatniego opowiadania Ostatnia podróż Ijona Tichego z 1999 roku). W latach 1993-1998 Lem publikował również eseje naukowe w polskiej edycji czasopisma „PC Magazine”, w których rozważał problemy biologicznej i sztucznej inteligencji, rozwoju informatyki oraz wynikającego stąd lawinowego przyrostu informacji w nauce i problemów z jej opanowaniem. Eseje zostały zebrane w zbiorze Tajemnica chińskiego pokoju (1996) oraz jego kontynuacji: Bomba megabitowa (1999). W 2003 roku oba zbiory zostały wydane pod nazwą Moloch przez Wydawnictwo Literackie. 
(2) o świat: jaki jest i jak go można zmieniać?; i (3) o Boga: czy jest coś poza światem widzialnym, czy istnieje i jaki jest świat niewidzialny? Zjawisko sztucznej inteligencji jeszcze bardziej kieruje ku odwiecznemu rozważaniu o tym, co decyduje, że jako ludzie różnimy się od świata i naszych własnych wytworów. Co jest istotą naszego człowieczeństwa - naszej wyjątkowości w świecie przyrody, naszej podmiotowości? Czy natura ludzka jest niezmienna, niezbywalna, nieprzekazywalna?

Pytaniem o naturę człowieka zajmuje się antropologia. Refleksja nad istotą człowieczeństwa jest tak pojemna i trudna w doprecyzowaniu, że powstało bardzo wiele odmian „antropologii”, w dużej mierze zależnych od wstępnych założeń światopoglądowych: antropologia filozoficzna, antropologia chrześcijańska, czy też religijna. Wyróżnia się też wiele specyficznych antropologii ze względu na badane obszary: antropologię biologiczną (fizyczną), antropologię psychologiczną, antropologię religijną, antropologię społeczną (popularna w UK), antropologię kulturową (popularna w USA). Próbując wyjść poza założenia światopoglądowe, warto prześledzić historycznie jak człowiek był coraz bardziej świadomy swojej odmienności od świata przyrody i poznawał istotę swojej natury.

Pierwsza spisana refleksja antropologiczna zawarta jest w mitologii sumeryjskiej. Cywilizacja Sumerów (ok. 3800-2000 przed Chr.) osiągnęła apogeum świetności między III a II tys. przed Chr. Wtedy powstały pierwsze poematy opowiadające o bogach, z których najstarsze spisane zostały ok. 2500 lat przed Chr., a późniejsze ok. 1700 lat przed Chr. ${ }^{2} \mathrm{~W}$ najstarszych mitach kosmologicznych bóg powietrza Enlil, po oddzieleniu nieba i ziemi, sporządził motykę i zrobił nią dziurę w ziemi, wyrósł pierwszy człowiek jak roślina. Enlil stworzył człowieka i pozostawił go samemu sobie. Według innego mitu: bogowie byli zmęczeni ciężką pracą w trosce o zapewnienie sobie pożywienia. Bóg Enki po upojeniu się piwem $z$ boginią Ninmah wpadł na pomysł zrobienia $z$ gliny formy prymitywnego robotnika, któremu dałaby życie bogini Ninmah (Bogini Matka, Pani Nieba). Enki dbał, aby była w nim zrównoważona strona dobra i zła. Pierwsze egzemplarze były nieudane i bogowie powtarzali próby, aż powstali ludzie, a ich zasadniczym obowiązkiem było wyręczanie bogów w pracy i zapewnienie im pożywienia. Człowiek jest więc istotą żywą stworzoną do pracy i składa się z pierwiastka ziemskiego i boskiego, jest dobry i zły, jednak po śmierci przechodzi w nicość - do Domu Prochu. W odróżnieniu od bogów człowiek jest śmiertelny i zamieszkuje ziemię.

W starożytnym Egipcie (III tys. - I tys. przed Chr.) egipscy kapłani stworzyli koncepcję człowieka złożonego z ciała i duszy. Według wierzeń egipskich bóg

Mitologia sumeryjska jest znana głównie z eposu o Gilgameszu i babilońskiego poematu o stworzeniu świata Enuma Elisz. 
Chnum (przedstawiany jako mężczyzna z głową barana) ulepił ciało (Khat) na kole garncarskim. Chnum stworzył również Ka (energię życiową) i razem z Khat umieścił je wraz ze swoim nasieniem w łonie matki. Stąd człowiek składa się z następujących części: Ren (imię, jako podstawa bytu jednostki; znajomość czyjegoś imienia dawała władzę nad tą osobą), Ba (dusza, osobowość, charakter danej osoby, budząca potrzebę jedzenia i picia, istota seksualności), Szeut (cień, który nieodłącznie podąża za każdym człowiekiem), Ib (serce, siedlisko emocji i woli, wiązało się z istotą życia, inteligencją i poczuciem moralności), $K a$ (energia życiowa podtrzymywana przez jedzenie i picie), oraz Khat (ciało). Po śmierci człowieka egipski bóg księżyca i patron mądrości Thot ważył jego serce Ib na wadze i gdy okazywało się cięższe od strusiego pióra jego małżonki Maat, bogini porządku, harmonii i sprawiedliwości, pożerała je Ammit (Pożeraczka Dusz, która z wyglądu przypominała skrzyżowanie lwa, krokodyla i hipopotama). Gdy serce było lżejsze od pióra, zmarły zostawał ogłoszony jako „mówiący prawdę" i pozwalano reszcie jego ducha na dołączenie do życia pozagrobowego. Po śmierci człowiek żył pod postacią Ach (duch), na którego składa się Ka i Ba spojone przez Ren, pozbawione Khat, Ib i Szeut. Człowiek w starożytnym Egipcie miał nieśmiertelną duszę, nieśmiertelne życie i nieśmiertelne imię.

Staroindyjską myśl filozoficzno-religijną (ok. 1500-500 przed Chr.) ukazują teksty Wed - świętych ksiąg hinduizmu, w szczególności najstarsze zbiory kanonicznych tekstów bramińskich - cztery sanhity. Jedna z sanhit, Rygwe$d a$, podaje, że bogowie złożyli w ofierze Puruszę - Pierwotnego Człowieka zrodzonego przez Brahmę - pierwszą żywą, ale śmiertelną i odradzającą się istotę. Purusza był kosmicznym gigantem, którego kończyny wyznaczały strony wszechświata, a jego ciało było światem materialnym złożonym z tysiąca głów i z tego ciała narodził się świat i społeczeństwo. Z jego ust narodzili się bramini (kapłani, których zadaniem było nauczanie), z ramion powstali kszatrijowie (wojownicy sprawujący władzę i opiekę nad ludem), z bioder powstali wajśjowie (rolnicy, kupcy i rzemieślnicy), a ze stóp powstali siudrowie (najniższa warstwa ludzi pełniąca funkcje służebne wobec wyższych stanów). Ofiara Puruszy dała też początek wszystkim zwierzętom, roślinom, świętym słowom, obrzędom i rytuałom. Człowiek mieści się w grupie udomowionych zwierząt obok krów, koni, kóz i małp. O jego najwyższej godności świadczy to, że różni się od nich umiejętnością składania ofiar i przez określone sposoby życia może wyzwolić się z cyklu reinkarnacji. Życie i uczynki zgodne $z$ dharma (prawo etyczne dotyczące powinności społecznych i religijnych) skutkują wcieleniem się po śmierci w lepszy byt, zaś pogarszanie własnej karmy powoduje wcielenie się w gorszy byt. Ostateczne wyzwolenie przysługuje ludziom tylko z najwyższych kast społecznych. Według staroindyjskiej myśli człowiek jest elementem świata 
poddanym w szczególności społecznym i religijnym normom etycznym i cyklowi umierania i odradzania.

Antropologia biblijna bazuje na pierwszych rozdziałach Księgi Rodzaju. Umiejscowiony w rozdziale drugim i trzecim opis stworzenia świata (jahwistyczny) jest starszy i powstał w IX wieku przed Chr. Opis stworzenia świata w pierwszym rozdziale Księgi Rodzaju (elohistyczny) powstawał pomiędzy 530-450 przed Chr. Według tej antropologii człowiek to: (a) ostatni w element w dziele stwarzania i najbardziej złożony; (b) jest powołany do panowania nad wszystkim, co stworzone; (c) jest stworzony na obraz i podobieństwo Boga.

W starożytnej Grecji nastąpił dalszy proces wyjaśniania istoty człowieka, co w sposób symboliczny ukazuje napis wyryty na architrawie delfickiej Świątyni

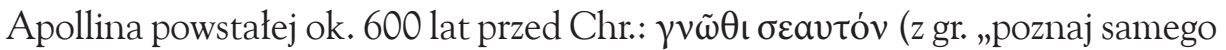
siebie"). Począwszy od VI wieku przed Chr. zaczął tworzyć się dramat antyczny w starożytnej Grecji, a za głównego twórcę starożytnej tragedii uważa się Ajschylosa z Eleusis (525-456 przed Chr.). Na scenie dionizyjskich przedstawień chóralnych, w którym brał dotychczas udział tylko chór i solista jako pierwszy dramatopisarz ograniczył rolę chóru i wprowadził na scenę drugiego aktora, a w swoich późniejszych tragediach trzeciego aktora ${ }^{3}$, co znacznie ożywiało dialog. Chociaż Ajschylosa nie interesowała psychologiczna głębia postaci, to jego bohaterowie ginęli ocalając swoją ludzką godność. Aby aktorzy na scenie byli właściwie identyfikowani z określoną postacią zakładali na twarz maskę zwaną „osoba” (gr. $\pi \rho o ́ \sigma \omega \pi \mathrm{ov}$, łac. persona) i w ten sposób odgrywali rolę konkretnej postaci. Słowo osoba nabrało z czasem znaczenia poza sztuką dramatu antycznego: realnego człowieka, który przeżywa dramat w życiu. Osoba to podmiot o rozumnej naturze, którym może być człowiek, a także bóg, jako byt wyróżniający się najdoskonalszą formą istnienia. Dramat grecki przyczynił się więc do pojmowania człowieczeństwa wyróżniając tożsamość osoby i jej dialogiczność na podobieństwo bogów.

W starożytnej filozofii greckiej Sokrates (469-399 przed Chr.) stwierdził, że posiadanie duszy odróżnia człowieka od zwierząt i reszty natury. Uczeń Sokratesa, Platon (428-348) twierdził, że dusza istnieje w świecie idei, więc jest nieśmiertelna. Składa się z rozumu, popędliwości i pożądliwości. Każda część duszy dąży do najwyższej idei dobra. Celem rozumu jest mądrość, celem popędliwości męstwo, celem pożądliwości umiarkowanie. Harmonię zapewnia sprawiedliwość. Razem tworzą cztery cnoty kardynalne. Dusza wchodząc w materialne ludzkie ciało traci wiedzę idealną, zapomina o ideach. Zdobywanie wiedzy staje się przypominaniem wiedzy idealnej. Uczeń Platona, Arystoteles

Trzeciego aktora na scenę wprowadził również młodszy i konkurujący z Ajschylosem Sofokles (496-406 przed Chr.) i to na dużo większą skalę, eksponując ten sposób związki interpersonalne postaci $\mathrm{w}$ dramacie antycznym. 
(384-322 przed Chr.) w sposób bardziej rozbudowany opisał czym człowiek różni się od innych stworzeń. Ucząc małe dzieci doszedł do wniosku, że ludzki umysł stanowi „czystą tablicę” zapisywaną wiedzą zdobywaną przez doświadczenie. Wiedza ta jest jednak chaotyczna, więc dla jej uporządkowania potrzebne są zasady prawidłowego myślenia. W tym celu Arystoteles stworzył logikę. Według niego posiadanie rozumu było czymś wyjątkowym. Formą życia organicznego jest wprawiająca materię $w$ ruch dusza. Pierwotnym źródłem ruchu materii jest nieruchomy, wieczny i doskonały Pierwszy Poruszyciel, a świat jest wprawiany w ruch przez tkwiącą w nim tęsknotę do doskonałości. Dusza dzieli się na trzy sfery: (a) wegetatywną (rodzenie, odżywianie i wzrost - wspólne dla roślin, zwierząt i ludzi); (b) zmysłową (postrzeganie zmysłowe rzeczywistości, motoryka, ruch w przestrzeni - wspólne dla zwierząt i ludzi); (c) oraz rozumną (rozumienie świata i samoświadomość, namysł i wybór - właściwe tylko ludziom). Dusza rozumna dzieli się na rozum bierny - receptywny, i czynny - niepowiązany z materią i nieśmiertelny.

Grecja nie sformułowała jednak pojęcia godności człowieka. Pojęcie to wprowadził rzymski filozof Marcus Tullius Cicero (106-43 przed Chr.) w dziełach De re publica (O wspólnocie, z 51 r. przed Chr.) i De officiis (O obowiazkach, z 44 r. przed Chr.). Odróżnia on dwa rodzaje godności - indywidualną i społeczną. Godność indywidualną otrzymuje człowiek przy urodzeniu. Jest darem, którego źródeł Cicero nie wyjaśnia. Godność odróżnia człowieka rozumnego od zwierząt i nie można mu jej odmówić, ale człowiek może tę godność utracić. Utrzymanie godności wymaga odpowiedniego zachowania. Godność społeczną wywodzi Cicero z pojęć: chwała, honor i sława. Nie jest ona cechą człowieka, ale „zasługą”. Godność indywidualną trzeba utrzymać, na godność społeczną trzeba sobie zasłużyć.

Antropologia filozoficzna św. Augustyna z Hippony (354-430) zakładała dualizm ontologiczny człowieka. Naturę człowieka tworzy zjednoczenie duchowej niematerialnej rozumnej duszy stanowiącej o godności człowieka i materialnego ciała mającego naturę zwierzęcą. Augustyn określa więc człowieka jako stworzenie rozumne śmiertelne (łac. animal rationale mortale). Dusza jest zdolna do więzi z Bogiem (łac. capax Dei) i posiada trzy władze: umysł, samopoznanie, miłość, a ich wzajemne odniesienie jest na wzór Trójcy Świętej. Dalszą refleksję nad pojmowaniem osoby podjął rzymski filozof i teolog chrześcijański Boecjusz (477-524) w traktacie Contra Eutychen et Nestorium doszedł do definicji osoby jako indywidualnej substancji natury rozumnej, która dotyczy zarówno osoby Boskiej jak i osoby ludzkiej.

Nurt refleksji chrześcijańskiej osiąga najbogatsze rozwinięcie w antropologii metafizycznej św. Tomasza z Akwinu. Opisuje on istotę człowieka najbardziej szczegółowo, asymilując przy tym podejście filozoficzne Arystotelesa. Akwinata 
zdefiniował człowieka jako byt istniejący w złożoności ciała materialnego i duszy rozumnej. Jest i duszą i ciałem. To hylemorficzna jedność substancjalna, czyli jedność materii (ciała) i formy (dusza). Dusza może osiągnąć złożoność na trzech poziomach: (a) dusza wegetatywna - rodzenie, odżywianie się, wzrost; (b) dusza zmysłowa - postrzeganie zmysłowe, ruch przestrzenny; (c) dusza rozumna - poznanie, namysł, wybór, samoświadomość. Rośliny mają jedynie duszę wegetatywną, zwierzęta - wegetatywną i zmysłową. Ludzie mają duszę wegetatywną, zmysłową i rozumną, która nie jest złożeniem trzech, ale jest jedną substancją. To dusza rozumna decyduje o wyjątkowej przynależności do rodzaju ludzkiego. Dusza po śmierci ciała może istnieć oddzielnie, bo jest nieśmiertelna. Jednak do poznania dusza ludzka potrzebuje ciała, gdyż do poznania niezbędne są postrzeżenia zmysłowe. Święty Tomasz mówił o poznaniu najpierw przez doświadczenie zmysłowe, by potem przejść do poznania umysłowego za pomocą intelektu. Poznanie miało charakter receptywny przez zmysły, a uzyskane na tej drodze dane opracowywane były przez rozum. Akwinata dokonał rozróżnienia między zmysłami zewnętrznymi (odpowiedzialne za kontakt ze światem zewnętrznym - 5 zmysłów: dotyk, smak, węch, słuch i wzrok) i wewnętrznymi. Cztery zmysły wewnętrzne pozwalają, aby umysł $\mathrm{w}$ dalszej fazie poznania zgłębił naturę danego przedmiotu:

Zmysł wspólny (sensus communis): (a) wydaje sąd stwierdzający, że dokonuje się postrzeganie przez zmysły zewnętrzne - „widzę, że widzę”; (b) rozróżnia zmysłowe jakości właściwe dla poszczególnych zmysłów: oko - np. kolor żółty; smak - np. słodycz; węch - np. zapach kwiatu lipy; dotyk - np. kleistość; (c) rozróżnia „wspólne przedmioty zmysłowe” nieuchwytne przez konkretne zmysły, np. ruch, liczba, kształt, wielkość.

Wyobraźnia (imaginatio): (a) przechowuje zmysłowe obrazy poznawanych przedmiotów; (b) przedstawia rzeczy w wyobraźni nieobecne dla poznającego (apparitio); (c) zespala obrazy w nowe formy poznawcze (np. czerwony koń), co można nazwać „fantazją”.

Władza osądu myślowego (vis cogitativa): (a) dostrzega abstrakcyjne cechy przedmiotu nieodebrane przez zmysły zewnętrzne (np. szkodliwość, użyteczność, odpowiedniość, wrogość, przykrość); (b) działając pod wpływem intelektu ludzkiego wyprowadza szczegółowe wnioski z podanych przez intelekt czynny przesłanek; (c) zestawia ujęcia szczególowe ujmując przedmiot jednostkowy jako należący do wspólnej z innymi natury.

Pamięć (memoria): przechowuje dokonane ujęcia aktów władzy osądu myślowego.

Tak szczegółowe rozróżnienie władz poznawczych zmysłów zewnętrznych i wewnętrznych bardzo dobrze ukazuje elementy, które sztuczna inteligencja potrafi coraz lepiej naśladować. 
Dla lepszego rozumienia sztucznej inteligencji warto jeszcze zwrócić uwagę na antropologię fenomenologiczną i nurt personalizmu w filozofii nowożytnej, która wyeksponowała i rozwinęła niektóre określenia dotyczące osoby ludzkiej zawarte już u św. Tomasza. Dwudziestowieczni egzystencjaliści Karl Jaspers i Jean-Paul Sartre i fenomenolodzy Martin Heidegger, Paul Ricoeur, Emmanuel Levinas podkreślili relacyjny aspekt natury ludzkiej ukierunkowującej człowieka ku innym ludziom - społeczny wymiar człowieka. Człowiek jest bytem relacyjnym i istnieje naprawdę wtedy, gdy istnieje w relacji do drugiego, i ta relacja jest wbudowana na miłości, i w miłości osiąga pełnię realizacji.

Personalizm chrześcijański (który reprezentują myśliciele: Max Scheler, Jacques Maritain, Emmanuel Mounier, Karol Wojtyła, Tadeusz Styczeń) podkreśla osobę jako fundamentalne pojęcie, które określa rzeczywistość i ją porządkuje. Osoba posiada wyjątkową wartość i transcendentny charakter. $\mathrm{Na}$ niej ogniskuje się cała rzeczywistość i podporządkowuje całe życie społeczne, aby jak najlepiej służyło rozwojowi człowieka, którego nigdy nie można traktować jako przedmiot, narzędzie, środek, bo on sam zawsze stanowi podmiot i cel. Jan Paweł II w Warszawie podczas pielgrzymki do Polski w 1979 roku posunął się nawet do stwierdzenia, że „nie można do końca zrozumieć człowieka bez Chrystusa”. Cały nurt myśli chrześcijańskiej przekłada się na praktyczne życiowo moralne nauczanie Kościoła katolickiego, które widzi człowieka jako istotę wezwaną do wypełniania woli Bożej, istotę która posiada świadomość, rozum i wolną wolę i jest obdarzona sumieniem, a przez to zdolna do aktu ludzkiego, który ma charakter podmiotowy. Na jego decyzje wpływają inni ludzie, świat, emocje, sumienie i poruszenia duchowe. Człowiek jest wezwany do miłości, ofiary i przekraczania samego siebie, by coraz bardziej stawał się na obraz i podobieństwo Boga w Trójcy Świętej.

$\mathrm{Z}$ drugiej strony istnieją poglądy radykalnie odmienne. Istniała i istnieje obecnie dyskusja uwarunkowana światopoglądowo na temat natury ludzkiej. Nick Bostrom, szwedzki badacz sztucznej inteligencji definiuje w transhumanizmie naturę ludzką jako proces tworzenia się, wypracowywania, który to proces możemy kształtować według naszych zamiarów i przy użyciu nowoczesnych technologii ${ }^{4}$.

\section{Sztuczna inteligencja w porównaniu z człowiekiem}

Po próbie zdefiniowania podmiotu trzeba spojrzeć na przedmiotową stronę zagadnienia i pokrótce przedstawić proces powstania AI: jaki jest rozwój elektroniki i informatyki i jak coraz bardziej upodabnia ten produkt do człowieka,

4 Por. N. Bostrom, Transhumanist Values, [w:] Ethical Issues for the 21st Century, F. Adams (red.), "Philosophical Documentation Center Press", 2003, 4. 
który jest jego stwórcą? Historia AI zaczęła się od mechanicznych urządzeń liczących szybciej niż człowiek, na większych liczbach i bezbłędnie, jednak ta ścieżka rozwoju zanikła. Wraz z odkryciem elektrostatyki rozpoczęła się druga ścieżka. Rozwijała się ona poprzez rozwój elektryczności i wejście w fazę elektroniki z wykorzystaniem lamp elektronowych i komputerów analogowych, ale zanika pod wpływem pojawienia się kolejnej fazy cyfrowej. Trzecia faza cyfrowa zaczęła się od zastosowania półprzewodników i logiki binarnej, tworzyła coraz bardziej złożone układy scalone, sieci logiczne, mikroprocesory, komputery cyfrowe wraz oprogramowaniem opartym na algorytmach, co pozwoliło osiągnąć wielką moc obliczeniową i tworzyć układy sztucznej inteligencji na znaczącym już poziomie. W międzyczasie w cyfrowej fazie trzeciej następuje rozwój Internetu i tendencji łączenia oddzielnych komputerów i systemów między sobą, $z$ bazami danych o ogromnych pojemnościach pamięci i wszechobecnymi czujnikami, sondami i receptorami, a nawet urządzeniami codziennego użytku. Nawet lodówka może otrzymać swoją tożsamość w takiej sieci za pomocą przydzielonego unikalnego adresu IP, a bazy danych w Internecie wiedzą prawie wszystko na temat naszego osobistego życia, jakby nas „osobiście” znały. Powstająca sieć zaczyna przekraczać ludzkie możliwości zarządzania informacją i zaczyna dotykać każdego aspektu życia pojedynczego człowieka. Jednak dopiero kolejna czwarta faza rozwoju, która zaczęła naśladować budowę komórek ludzkiego mózgu otworzyła wcześniej nieosiągalne możliwości samouczenia się, rozpoznawania stanów i przewidywania wyników. Rozpoczęła się ona od odejścia od logiki binarnej w kierunku układów logiki rozmytej (ang. fuzzy logic) i sieci neuronowych. Tworzy układy, które same się uczą, jak człowiek, na przykładach, ale mają dużo większą szybkość działania i nieosiągalny dla człowieka zakres uczenia się i potem rozpoznawania i przewidywania nowych sytuacji na podstawie nauczonych przykładów. Sztuczna inteligencja w obecnej fazie rozwoju oparta jest głównie na sieciach neuronowych i olbrzymich zasobach informacji zawartych w bazach danych. Stoimy również na progu fazy piątej kwantowej - opartej na bitach kwantowych (qbit) i przetwarzaniu informacji kwantowej, która tworzy układy, komputery i transmisję kwantową. Otwiera to niewyobrażalne dla laika możliwości obliczeniowe i szybkość komunikacji. Należy wspomnieć również o rozwijanej ścieżce układów analogowych i cyfrowych opartych na materiałach biologicznych, jak również rozwoju technologii zapisu informacji, która obecnie gwarantuje coraz to większe „upakowanie” informacji i trwałość nawet w nieprzyjaznych warunkach osiągającą miliardy lat (jak laserowy zapis na płytkach kwarcowych), co jest porównywalne z szacowanym wiekiem wszechświata! Technologia rozwija się w różnych kierunkach i w bardzo szybkim tempie liczonym latami, a nawet miesiącami. W odróżnieniu od refleksji nad istotą człowieczeństwa, która biegała przez tysiąclecia, refleksja 
nad sztuczną inteligencją przebiega przez ostatnie kilkadziesiąt lat, czyli ok. tysiąckrotnie szybciej. Bostrom przypuszcza, że sztuczna inteligencja dorównująca ludzkiej może zostać opracowana do połowy XXI wieku, a stosunkowo szybkim następstwem będą systemy superinteligentne, które mogą przynieść bardzo duże korzyści, ale również zagrożenie całego gatunku ludzkiego5.

\section{Porównanie}

Aby porównać człowieka i sztuczną inteligencję, należy lepiej poznać to, co wspólne i to, co różni. Wspólne cechy to: 1. Pamięć, 2. Proces uczenia się na przykładach i zapamiętywania, 3. Podobna struktura mózgu i sieci neuronowych, 4. Podobny proces: sygnały na wejście, sygnały na wyjście (reakcja), 5. Umiejętność liczenia, stosowania logiki i sposób ważenia decyzji, 6. Wspólna jest również podatność na zakłócenia, występowanie błędów i stanów nieustalonych.

Różnice to: 1. Ciągłość procesu - u człowieka nie da się przerwać dynamiki procesu myślenia, inaczej mówiąc, wyłączyć go i włączyć ponownie - zrestartować do stanu tabula rasa (niezapisana tablica). Można co najwyżej zamrozić stan; 2. Niepowtarzalność człowieka w odróżnieniu od kopiowalności/zastępowalności/identyczności sztucznych układów. Nie da się powielić ukształtowanej inteligencji za pomocą przeniesienia parametrów układu na inny identyczny układ; 3. Samoświadomość ludzka często łączona z właściwościami duszy; 4. Na korzyść maszyny jest szybkość operacji, np. uczenia się na przykładach, objętość informacji, złożoność operacji, komunikowalność z innymi maszynami, brak procesu zapominania, zmęczenia.

Nie jest to porównanie, które ciągle ulega zmianom, ponieważ AI cały czas podbija nowe obszary i nabywa nowych podobieństw do człowieka np. tych opisanych przez Tomasza z Akwinu czy podobieństw do fizycznej pracy mózgu. Dla przykładu: o ile w sieci neuronowej potrafimy określić wagi każdego z połączeń, o tyle stany w kwantowych bramkach logicznych są oparte na prawdopodobieństwie i nie są przez nas mierzalne. Nie możemy ich skopiować, czy też przerwać konfiguracji stanów kwantowych i potem w pewnym momencie je wznowić. Sztuczna inteligencja ma więc dalszą drogę otwartą do upodabniania się do człowieka przyjmując cechę ciągłości procesu i niepowtarzalności.

Próbę porównania człowieka z maszyną podjął brytyjski matematyk, kryptolog, uważany za ojca sztucznej inteligencji Alan Mathison Turing (19121954) za pomocą myślowo skonstruowanego testu Turinga. W 1950 roku zaproponował on, by możliwość udawania człowieka w zdalnej rozmowie uznać za test inteligencji maszyn. Od tego momentu układy sztucznej inteligencji

Por. N. Bostrom, Superinteligencja. Scenariusze, strategie, zagrożenia, Gliwice 2016, s. 44. 
poddawane są tej niejednoznacznej, ale istotnej formie sprawdzenia. W 2018 roku Korporacja Google pochwaliła się przeprowadzonym testem, w którym sztuczna inteligencja oparta na systemie Android Duplex głosowo odebrała od człowieka zadanie umówienia go na poranne strzyżenie we wtorek. System sam odnalazł najbliższy zakład fryzjerski, zadzwonił i kobiecym głosem przeprowadził 57-sekundową rozmowę, podczas której ustalił z pracownicą salonu, która sądziła, że rozmawia z inną kobietą, termin strzyżenia i dodatkowe opcje usługi.

Zawołanie: „poznaj samego siebie” wskazuje na równoczesną obecność w człowieku dwóch diametralnie różnych perspektyw. Z jednej strony, perspektywy podmiotowej, a z drugiej, przedmiotowej. Człowiek reflektuje nad samym sobą, jako przedmiotem (fizyczne funkcjonowanie, przemieszczanie, wykonywanie zadań), a przy tym towarzyszy mu refleksja widzenia siebie jako podmiotu tego aktu. Wynika to z umiejętności zajęcia zdystansowanej wobec siebie pozycji, poznawczego wykroczenia poza siebie. Wyjaśnienie tej ludzkiej możliwości w kontekście fizyczno-biologicznej konstrukcji człowieka, stanowi fundamentalne pytanie antropologii filozoficznej jak również cel stawiany przed sztuczną inteligencją.

\section{Zadziwienie i pytania etyczno-moralne}

Bóg stworzył człowieka na swój obraz i podobieństwo ( $\operatorname{Rdz} 1,26 n)$, a człowiek, podobnie jak Stwórca, zaczyna tworzyć dzieła coraz bardziej na swój obraz i podobieństwo. Bóg stworzył człowieka, który był dobry, ale nie lepszy od Boga pod żadnym względem. Człowiek zaś zaczyna tworzyć dzieła, jak np. układy sztucznej inteligencji, które są lepsze, przewyższają swojego stwórcę! Sztuczna inteligencja już od dawna jest lepsza w liczeniu, od niedawna lepsza w zapamiętywaniu i gromadzeniu informacji, w grach logicznych, a od bardzo niedawna lepsza w obróbce informacji (rozpoznawanie, analiza). Zaczyna też rozpoznawać i naśladować stany emocjonalne człowieka. Zaczyna też wchodzić w zupełnie nowe obszary niedostępne człowiekowi. Konstruuje się już urządzenia, które z fal mózgowych potrafią odczytywać, na razie w zarysie, myśli ludzkie i takie urządzenia, którym człowiek zaczyna za pomocą myśli wydawać proste rozkazy.

Człowiek konstruuje stworzenia doskonalsze od siebie, czyli bliższe pierwotnego Stwórcy. Zaczął tworzyć technologie, które są równie trwałe, można rzec wieczne, jak stworzony przez Boga wszechświat. Czy więc może człowiek już tworzyć istoty na wzór i podobieństwo nie tylko swoje, ale i Boże? Czy maszyna, sztucznie stworzona przez człowieka inteligencja dogoni człowieka we wszystkim? Czy osiągnie poziom podmiotowości człowieka? Czy są może obszary, których stworzona przez człowieka inteligencja nigdy nie osiągnie - np. 
samoświadomość? Czy można dążyć do stworzenia niesterowalnej sztucznej inteligencji, która sama będzie decydować o kierunkach własnego rozwoju, a nawet form życia opartych na replikacji i udoskonalaniu? Czy etycznie moralne jest produkowanie dziś urządzeń opartych na AI, które podejmują autonomiczne decyzje kogo uratować (medycyna), a kogo zabić (wojsko)? Czy może to być zagrożenie dla gatunku ludzkiego? Czy jest to nasze powołanie by stworzyć, jak Bóg, własną istotę, która stanie się niezależna, będzie na nasz obraz i podobieństwo i będzie miała wolną wolę? Jak projektować sumienie, czy też system etyczny, którym kierowałyby się takie urządzenia? Jaki respekt należy okazywać takiej maszynie i czy będzie porównywalny do godności człowieka? Czy etyczne jest, aby maszyna udawała człowieka, jak to uczyniła w eksperymencie Google? Czy nie jest to masowe oszukiwanie ludzi? Na ile sztuczna inteligencja może zastępować pewne układy w organizmie człowieka, by był zdrowszy, lepszy, wieczny? Te oto pytania do tej pory ze sfery fantastyki naukowej stały się elementem naszej rzeczywistości.

Słowa kluczowe: antropologia, sztuczna inteligencja, osoba, natura ludzka, tożsamość, godność, personalizm, transhumanizm.

\section{Bibliografia:}

1. Bostrom N., Transhumanist Values, [w; Ethical Issues for the 21st Century, F. Adams (red.), "Philosophical Documentation Center Press" (2003): 3-14.

2. Bostrom N., Superinteligencja. Scenariusze, strategie, zagrożenia, Gliwice 2016. 